\title{
English as a Medium of Instruction at Turkish State Universities
}

\author{
Reninni Taquini \\ Universidade Federal do Espírito Santo (UFES), Brazil \\ Av. Fernando Ferrari, 514 - Goiabeiras, Vitória - ES, 29075-910, Brazil \\ E-mail: rtaquini@gmail.com \\ Kyria R. Finardi (Corresponding author) \\ Universidade Federal do Espírito Santo (UFES), Brazil \\ Av. Fernando Ferrari, 514 - Goiabeiras, Vitória - ES, 29075-910, Brazil \\ E-mail: kyria.finardi@gmail.com
}

Gabriel B. Amorim

Universidade Federal do Espírito Santo (UFES), Brazil

Av. Fernando Ferrari, 514 - Goiabeiras, Vitória - ES, 29075-910, Brazil

E-mail: gabrielbamorim@gmail.com

Received: June 1, 2017 Accepted: June 20, $2017 \quad$ Published: June 22, 2017

doi:10.5296/elr.v3i2.11438 URL: http://doi.org/10.5296/elr.v3i2.11438

\begin{abstract}
This paper reports a study that explores the role of English as a language of instruction (or English Medium Instruction (EMI)) in the Turkish higher education system problematizing it in Turkey in terms of the country's possible inclusion in the European Union and globalization discourses as well as the possible exclusion of Turkish students who do not speak English. With that aim, a study was carried out to analyze the offer of EMI courses at the Turkish universities and the use of English in that context. Data were collected from the Turkish universities websites and the analyses show that there are more state than private universities in the country, most of which have websites in English whereas only $25 \%$ offer
\end{abstract}


EMI courses and/or programs to attract international students. The discussion of the data addresses the use of English in the internationalization of higher education in relation to possible implications of offering EMI courses in that context.

Keywords: Internationalization, English Medium Instruction, Turkey

\section{Introduction}

Globalization has made the use of English indispensable to those who wish to exercise a global citizenship as well as to those nations that wish to adhere to global markets and/or obtain international visibility. Regarding the role of English in the process of internationalization of higher education, the present study draws on results of previous studies carried out at Brazilian universities (for example Amorim \& Finardi, in press; Finardi \& Archanjo, 2015; Finardi \& França, 2016; Finardi \& Ortiz, 2015; Finardi \& Tyler, 2015; Finardi \& Ortiz, 2015; Finardi, Santos, Guimarães, 2016, Finardi, 2016a,b) and at a Swiss university (Finardi \& Csillagh, 2016; Finardi, 2017), to propose the reflection on the use of English in Turkish universities.

One motivation to pursue the study was related to a finding of two of the aforementioned studies (Finardi, Santos, Guimarães, 2016; Finardi \& Tyler, 2015) that most of the world top ranked universities were either in English speaking countries or in countries that adopted English as the medium of instruction (EMI), as a strategy to increase internationalization. According to the 2014 Quacquarelli Symonds (QS) World University Rankings, only 40 out of the 100 best universities were in non-English speaking countries and only 14 non-English speaking universities were within the top 50. Another interesting finding of these studies was the observation that most of these non-English speaking universities had adopted English as the language of instruction - EMI, one exception being the University of Geneva (Unige), ranked in the 85th position and which motivated Finardi (2017) to investigate this university's status closer.

According to Vavrus and Pekol (2015) and Hamel (2013), and as reported in Finardi, Santos and Guimarães (2016), there seems to be a bias towards the English language which implies that English speaking countries and universities that offer EMI courses tend to benefit more from the advantages of globalization and internationalization of higher education than those which do not.

Though the focus of the present study is Turkey, the higher education scenario in Brazil will be briefly outlined here because Brazil shares many characteristics with Turkey, not only as a developing nation whose national language may represent a challenge to attract international students in the "internationalization at home" (Crowther et al., 2000), but also as a country struggling to keep up with the global internationalization agenda (Finardi, 2017). Another reason to briefly describe the situation in Brazil is that the present study partly draws on results found in Brazil as previously stated in the introduction to this paper.

Finardi (2016a, 2016b) describes Brazil as a developing country where English has the status of a foreign language that can both mean the inclusion of universities in the international scenario and the exclusion or threat to the teaching of other foreign languages as well as of Brazilian students who do not master the English language. According to recent data reported in Finardi (2016a), only about 5\% of Brazilians speak English fluently and because of the 
wish of most Brazilians to be included in global discourses and scenarios, as well as the wish of most Brazilian universities to become international, the offer of EMI courses in Brazilian universities faces many challenges (Martinez, 2016).

Because of the similarities between Brazil and Turkey in terms of the higher education scenario and the role of English in that context, as well as possible implications of the transfer of educational models of developed nations to developing ones (Akkari \& Gohard-Radenkovic, 2008), the present study aims to go a step further to discuss the role of the English language in Turkish universities. Turkey was chosen for this study based on the similarities it bears with the context described in Brazilian universities in the aforementioned studies and also due to its current relevance both to the East and West world, whose cultures differ very much and where the choice of English as a EMI in higher education means an opening and an approximation to Western countries in a key moment of Turkish history.

The offer of EMI courses in Turkish universities is a movement that connects Turkey to the European style and internationalization agenda at the same time that it represents a gap from western traditions in a crucial moment when Turkey applies to enter the European Union (EU). Because of the tension to maintain its language/culture as well as to obtain the language of international education (EMI), we think that the analysis of EMI (Note 1) in Turkey can add to the global discussion on the role of English as a whole (Finardi, 2016b).

The current political scenario in Turkey promotes bipolarity in relation to the English language, which, in turn, represents the West and its capitalist values threatening Turkish values in a type of "turkcide" of the local culture and language. In this context, the present study aims to contribute to the discussion on the role of English in the globalized world by analyzing the role of English in the historical/political moment represented by the domestic and international political polarization that Turkey is going through.

\section{Turkey}

The Republic of Turkey was founded right after the fall of the Ottoman Empire, in 1923, by Mustafa Kemal "Atatürk" (father of Turks), with social, political, economic, religious, and language reforms. Turkey is a transcontinental country located in Eurasia - its smaller portion, Thrace, located in Europe; and its largest part, Anatolia, located in Asia. It is an important country for intercultural relations between the west and the east due to its strategic location. It borders eight countries: Greece, Bulgaria, Georgia, Armenia, Azerbaijan, Iran, Iraq, and Syria. During the Ottoman Empire, the population spoke Ottoman Turkish, language with Arabic characters, which was substituted by the Latin alphabet in 1928, in order to modernize the nation. Turkey's official language is Turkish, and Kurdish is the second most spoken language, especially in the eastern part of the country, in the region called Kurdistan - the biggest nation in the world without a territory; it encompasses Turkey, Iran, Syria, and Iraq. The population surpasses 78 million people, with Istanbul as the most populated city with 13 million people. Turkey is divided into 81 provinces and Ankara is the capital.

Turkey also maintains a close relationship with Europe (the country started the negotiations to enter the EU in 2005), with the Middle East and Northern Africa due to organizations and conferences related to Islamism, the predominant religion in the country. Turkey is a secular country and does not possess official religion, despite the fact that $99 \%$ of its population 
declare themselves to be Muslims (Howard, 2001).

In regards to Turkey's imminent entrance in the European Union, the pros and cons are related to geographical, political, economic, and religious aspects. According to a European debate website (Note 2), geographically, Turkey represents a bridge between Asia and Europe, facilitating the relationship among its respective nations but also representing an entrance point to often undesired immigrants mostly from Syria and Iraq. According to the European commission, the number of refugees in Turkey has reached over 3.2 million (out of them, 2.7 million Syrians), making Turkey the host country with most refugees in the world. In order to cut numbers of refugees in the EU, Turkey has agreed to take back any asylum seekers who land in Greece, while in return the EU gives Turkey $€ 6$ billion to help refugee politics, as well as to make it easier for Turks to get visas and keep the idea of becoming a EU state member. 97\% of Turkey's territory is located in Asia, having Iran, Iraq, and Syria as its neighbors.

A population of 91 million people is predicted for 2050, making Turkey the most populated country of the EU if it enters this group. Politically, the EU would import the polarization between groups, those that are for and against the government and the problem with the Kurdish. Economically, Turkey would inject 75 million consumers in the European market. Despite its economic growth, the country is still developing and the wealth is distributed unequally. Religiously, Turkey might show Europe that it is open to the Islamic world, but it would have to adapt to Muslim traditions, which are fundamentally different from other European traditions. In this historical moment, when the president of the United States, Donald Trump, defends a decree prohibiting Muslims from entering the United States, Turkey's entrance in the EU would represent an important and symbolic step, as well as a statement.

Turkish communities in Germany as well as in other EU countries such as Austria are said to suffer from lack of integration. By way of example, in the neighborhood of Griesplatz in Austria, the Turkish community is segregated despite the debate in regards to the integration of Turkish students in the local school. According to an Austrian website (Note 3), the schools in this community do not serve pork and some music is considered taboo due to its content. With such characteristics, Turkey's possible entrance in the EU is at the center of the dualism of concepts that divide the population between keeping the Islamic traditions and opening up to the Western world.

In July 15, 2016, there was an attempt to a coup d'etat under the allegation that the current president would be trying to Islamize the country, being opposed to the secular state established by the country's founder Mustafa Kemal Atatürk. The theologian Fethullah Gülen, former ally of the current president Recep Tayyip Erdogan, who is currently in self-imposed exile in the United States, is accused by the president of leading the failed attempt of coup d'etat. The refusal on the extradition of the theologian weakened the relationship between Turkey and the United States and, as a direct consequence, with the West. As mentioned above, Trump's decree to ban and impede Muslims to enter the US only aggravated these relations, making Turkey's entrance in the EU even more complicated.

\section{The English language in the globalized world}

For all, the English language has become a lingua franca (Jenkins, 2013, 2015) in different 
contexts given the fact that the number of speakers of this language as an additional language has surpassed the number of native speakers of this language (Finardi, 2014). According to Finardi, Prebianca and Momm (2013), some knowledge of English is necessary to have access to the plethora of information available online and mostly in English and according to Finardi and França (2016), English is also necessary to access and circulate academic/scientific outputs. According to Crystal (2003), more than 75 countries or territories around the globe have English as their L1 or L2, totaling a number of approximately 980 million speakers of English (Note 4).

Given the relevance of this language in the international scenario, it is important to recognize that a developing country that is nearing its entrance in the biggest economic block in the world needs to acknowledge the importance of remodeling current language and educational policies aiming for growth and international recognition. At the same time, given the resistance to globalization forces, it is also paramount to acknowledge the need to find both a global and local solution for the matter.

The hegemony of the English language imposed in various contexts forces us to think of global and local implications of using this language and to conclude that, to be part of the globalized world, some knowledge of English is necessary to access information online (Finardi, Prebianca, \& Momm, 2013), education online in the form of Massive Online Open Courses (MOOCs) (Finardi \& Tyler, 2015), to circulate the academic production (Finardi \& França, 2016) and according to Jenkins (2013), to become an internationalized university for English has become the academic lingua franca of higher education.

Yet, it is important to note that despite the aforementioned benefits of having some knowledge of English, the uncritical adoption of English with an eye to internationalization can have serious negative effects such as the strengthening of colonization (Castro-Goméz, 2007) with its violent consequences to the colonized (Andreotti et al., 2015) "South" (Vavrus \& Pekol, 2015).

\section{Motivation to internationalization}

The internationalization of higher education, defined as the integration of an international, intercultural and/or global dimension in the function of education (Knight, 2003), follows global trends to connect countries and offers programs in English to attract international academics.

Finardi and Ortiz (2015) investigated the motivation of two Brazilian universities, one public and the other private, to become internationalized. The authors hypothesized that private universities, similarly to European universities after the withdrawal of public funding for education, would be motivated to become international as a way to attract foreigner-paying fees. Contrary to their expectations, the study found that the public university investigated (which is public and as such, does not charge fees or tuition in Brazil), was more motivated to become international than the private one. The authors explained this unexpected finding in terms of academic versus economic motivations for internationalization and the size of the domestic market in Brazil (private universities account for about $25 \%$ of the offer but the population in Brazil is so large that it still represents a comfortable market for private universities which do not need to seek financing outside Brazil). One of the lessons of Finardi 
and Ortiz' (2015) study is that internationalization of higher education may be closely associated with economic (and not only) academic motivations.

As pointed out by Kirkpatrick (2014), another reason to offer EMI courses is to improve international rankings of the universities. De Wit (2011) claims that the internationalization of universities are usually a good indicator of their quality (De Wit, 2011) and that, worldwide, the increase in the number of universities that offer EMI courses is more observed in the private sector (Kirkpatrick, 2014). Consequently, since very early ages, parents who can afford to, consider private English courses for their children aiming for the best universities and the possibility of living with international students in a culturally diverse environment (Csillagh, 2015). As pointed out by Finardi (2014) in relation to the role of English in private institutions in Brazil, the offer of English courses (be them in the form of general English courses or in the form of EMI courses) in the private sector, creates a social gap whereby only the economically privileged people can have access to this kind of knowledge and linguistic capital. To see how the role of English affected the internationalization of higher education in Europe the next section reviews the Bologna Process.

\section{The Bologna Process}

The Bologna Process was signed in 1999 by 29 European countries aiming at creating a convergence of higher education in the European Union, promoting student and faculty mobility, job opportunities, and collaborative research among countries and institutions.

The Bologna Process does not aim at the unification of curricula, but at the possibility of exchange without losing the autonomy and diversity of each institution. For that, the European Credit Transfer System (ECTS) was created, aiming at the validation of the credits of courses taken in the origin institution (Note 5). Nowadays, there are 47 countries participating in the Process, Turkey became a member in 2001 along with Croatia, Cyprus, and Liechtenstein.

According to the European Commission, the EU has 24 official and working languages. Differences in treatment among more and less powerful countries or among more popular and less popular languages cannot exist, so the Commission maintains the policy that all EU citizens should be able to write to the Commission and receive a response in their own language. Maltese, Slovak and Latvian should have the same status as English, French and German, for example. In order to make this possible, one of the largest translations services in the world is used. Citizens have equal access to information, showing the importance that each country has in the EU legislation.

Even though this discourse and logistics seem to work in the European Commission, the same does not happen when only one language is chosen to standardize teaching in higher education: the English language, first language of only two countries in the EU. According to Phillipson (2009), the Bologna Process is equated with internationalization of higher education in English. Because internationalization of higher education is very often equated with academic mobility, the next section reviews an important academic mobility program in Europe.

\section{Erasmus}

Erasmus is one of the biggest academic mobility programs in the world and was created by 
the European Union in 1987. It enables both European academics to study/work in all EU countries but also academics of other parts of the world to study/work in the EU. It was expanded in 2014 to Erasmus Plus (Note 6), and since then it administers both exchange programs outside the borders of the EU and coordinates educational, professional, and sports projects. The objective of this program is to expand trans-border cooperation among countries to motivate the exchange of academic and cultural abilities. According to the program's official website (Note 7), more than 4000 students are benefited at once. Students enrolled in this program may travel abroad for a minimum period of 3 months and a maximum of 12 months. The program is based on a three-cycle academic mobility - the first cycle is for bachelor's degree or equivalent, the second cycle aims at master's degree or equivalent and the third cycle is targeted at doctoral studies. Currently, there are more than 4000 higher education institutions in 37 countries that participate in the Erasmus program, and the number of universities and students that benefit from the program increase every year. According to the 2016 statistics (Note 8), the Erasmus program is promoting a series of parallel projects such as Youth Exchange (YE), Professional Development Courses (TC), European Volunteer Services (EVS), and the Erasmus for Young Entrepreneurs. According to the official statistics published by the European Commission (Note 9) in October of 2015, at the moment of the foundation of the program in 1987, 3,244 students of 11 municipalities benefited from the program. These numbers increased to 34 countries in 2013-2014, with 28 member countries of the EU and countries outside the EU such as Iceland, Turkey, and Macedonia. In 2013-2014, with a budget of 580 million euros, 272,000 students and 57,000 workers traveled abroad through Erasmus. According to the European Commission, an increase of $40 \%$ in the budget was given to Erasmus Plus to benefit more people and projects due to its increasing demand. Given the fact that the focus of this paper is to address the role of EMI in Turkish universities, the next section reviews a Turkish academic mobility program.

\section{Mevlana}

Mevlana is a Turkish exchange program that aims at academic exchange of students and workers among higher education institutions in Turkey and abroad. The mission of the program is to permit a global platform for students, culture exchange, and knowledge unification. Among the goals of the program are the reinforcement of the role of Turkey in higher education at an international level, the augmentation of the academic capacity of Turkish institutions, and the promotion of the historical and cultural legacy of the country (Note 10). The program was named after the philosopher Mevlana Jallal-u-din Rumi. According to the rules of the program (Note 11), students may travel abroad to study for 1 or 2 semesters and faculty may work abroad for a period of 1 week to 3 months. The program is available in different levels of higher education, that is, technological undergraduate courses, bachelor's degree courses, master's and doctorate courses. The program offers scholarships and different benefits such as the exemption of the tuition fee during the period of exchange in the partner institution (Note 12). According to the statistics published in the official page of the program (Note 13) in 2016, around 400 foreign students from 6 different universities went to Turkey via this program. In the same way, around 300 foreign faculty members in 5 different Turkish universities and around 300 Turkish workers were sent abroad. 


\section{English as Medium of Instruction}

As suggested by Finardi and Tyler (2015), many universities adopted English as the language of instruction (EMI) as a strategy to internationalize their institutions since English makes it possible to offer courses for students of different mother tongues and nationalities. The teaching of contents by means of additional languages is a new phenomenon in many places, including Brazil (Alencar, 2016), where only recently it is possible to observe some EMI courses in higher education (Martinez, 2016). In Europe and in Canada the Content and Language Integrated Learning (CLIL) approach has been used in different educational levels as a bilingual and multilingual approach whereas in the United States this approach has been more popular in higher education where it is sometimes known as Content-Based Instruction (CBI) or EMI, more often used in Europe and to refer to higher education.

The benefits of EMI are varied and go from the possibility of improvement in the additional language to a higher possibility of internationalization for the institution adopting it. Nevertheless, and as pointed out previously in this paper, the dangers of adopting EMI without critical analysis are also significant.

In Brazil, Alencar (2016) investigated the possibilities and limitations of implementing the CLIL approach in elementary education and concluded that the major obstacle would be to find teachers who are proficient both in the content and in the language being taught. We can infer that the challenges of implementing EMI in higher education in Brazil and in Turkey are similar to those pointed out by Alencar (2016) for CLIL in Brazil. However, given the benefits of EMI for the internationalization and as suggested by Finardi, Santos and Guimarães (2016), one could say that the reflection on the offer of EMI courses in these contexts is crucial for developing countries like Turkey, a potential candidate for the EU.

\section{Opposition to Internationalization}

The diffusion of English is not natural and may be related to a linguistic imperialism that aims at perpetrating the hegemony of the language because of international economic and political interests. The uncritical use of English can present serious consequences as previously mentioned here, among which Finardi (2014) claims is the social gap created by the uneven offer of courses in private and public institutions. Combined with the hegemony of the English language, before adopting EMI, it is necessary to reflect upon possible negative consequences such as the exclusion of those who do not speak this language. If, on the one hand, English increases the access to information (Finardi, Prebianca \& Momm, 2013) and to online education (Finardi \& Tyler, 2015), it also increases the social gap for those who do not have access to this linguistic and social capital (Finardi, 2014).

Many studies about English as a medium of instruction are done analyzing the level of English acquired by the students (Ament; Peres-Vidal, 2015; Rocha; Correa; Salgado, 2010; Lundin; Persson, 2015; Sylvén, 2015). Nevertheless, it is important to highlight that studies analyzing a possible linguicide or cultural threat as a consequence of adopting EMI at large are still lacking.

In the case of Oman, students do not have the right to study in higher education in their native language - Arabic - since all state universities utilize EMI. English is seen as a language that reflects international interest whereas Arabic is utilized for local communication (Al-Bakri, 
2015), rendering the use of Arabic hierchically determined to a second-best position in the country.

According to Al-Bakri (2015), in a study problematizing mandatory EMI in state universities in Oman, the lack of participation of students in EMI courses may be related to the fear of making a mistake in front of classmates and professors, for proficiency levels vary among these students. Students may understand the content though they may not know how to express themselves in English. The opposite case is also true, that is, some students may not grasp the content so well, but know how to express themselves in English, thus being assigned higher grades than those who cannot. Thus, different levels of proficiency in the content or in the language of instruction may generate negative results.

For countries whose population is mostly Muslim, Arabic represents the conservatives whereas English represents the modernists with their ensuing threat to the local culture. There are 24 Arabic speaking countries and they are primarily located in North Africa and the Middle East. In total, it is estimated that approximately 420 million people around the world speak Arabic, making it the sixth most spoken language in the world. The predominant religion in these countries is the Islam, and even in other Islamic communities around the world, Muslims are encouraged to learn Arabic. According to Ferguson (1970), since the Quran, the prayers, the greetings among Muslims and also the call for prayer are in Arabic, and even those who do not have Arabic as their first language know some terminologies in Arabic and use them in Arabic to sustain their true meaning, such as salam aleykum (peace be upon you), Allah (God), Allahu akbar (God is the greatest), jihad (struggle), inshallah (if God wills), halal (allowed), haram (forbidden), jannah (paradise) and hijab (cover/headscarf). Based on the frequent and spread use of these words, Ferguson (1970) suggests that Arabic works as a lingua franca among Muslims. It can be said that Arabic is a lingua franca among 1.8 billion people in the Muslim world. As stated by Arshad and Ahamad Shah (2014), Muslims have their own linguistic needs related to their faith and identity, with some words that Standard English often cannot convey, raising the awareness of an Islamic English (Al-Faruqi, 1986) Also, Arabic represents the Islamic culture. In some countries like Iran and Saudi Arabia, the Internet and television contents are controlled by the state and some themes are blocked as an attempt to avoid contact with the Western world. Just as the importance of English as a medium of international communication, business and education cannot be ignored, the significance of Arabic as lingua franca and language of religious practice and communication cannot be ignored among Muslims.

For students to achieve good proficiency levels in English, parents - with good financial situation, prepare their children to this new scenario, for example, looking for schools that adopt CLIL/EMI as early as primary education. This scenario has been described in terms of elite bilingual schools in Brazil by Liberali and Megali (2016). An elite school in Turkey adopted EMI in high school but abolished the method as soon as they realized that the performance of students in Mathematics and Science was below their expectations (Dearden, 2014). Because these elite students are the same ones who wish to study in EMI universities, it is crucial to consider their poor performance and reflect upon new practices so that students do not see the language as an obstacle in their studies.

Another point to consider is that students may acquire English without reflecting about the 
implications of using this languagein bilingual education contexts, thus contributing to the hegemony of English in the world and to possible threats to the local language/culture. The "E" in EMI is based upon a model of native speakers (Kirkpatrick, 2014) and it is important to acknowledge, as Finardi (2014) did in the case of Brazil, the dangers of linking a desired proficiency level to the notion of native speaker. So as to reflect on possible advantages and hurdles of adopting EMI in Turkey, a study was carried out to verify the number of Turkish State Universities that use EMI. The methodology used in the study will be described in the next section.

\section{Methodology}

Based on Finardi and Ortiz (2015) who found that state universities were more motivated to become international than private universities in Brazil, mainly because of the number of private versus state universities in Brazil, and based on studies that associate the offer of EMI courses with internationalization of higher education, this study aimed at verifying the number of state Turkish universities that adopt English as medium of instruction in at least one of their courses. For that, the study collected quantitative data by means of internet search in Turkish university websites excluding foundation universities (maintained by private groups and supervised by the government).

The search was initially made through a list containing all universities in the country, using the term "Turkish universities" and "Universities in Turkey". Through the website for international students (Note 14), a list with all state universities was put in alphabetical order. Next, the official website of each university (Note 15) was analyzed to check if they had a version in English and whether they offered courses in English or not.

According to the website "studyinturkey.com", Turkey has received 5,000 students from European universities whereas 9,000 Turkish students went abroad to study in foreign institutions. That is, similarly to what happens in Brazil, Turkey sends more academic nationals than receives academic foreigners, perhaps due to the language limitation since both Turkish and Portuguese are not considered lingua franca or international languages in the higher education context. Another possible explanation for the imbalance between the number of Turkish and Brazilian academics who go abroad to study and the number of academic foreigners who come to study in Turkey and in Brazil may be related to the level of internationalization of these universities (Jenkins, 2013). Lima and Maranhão (2009) claim that some universities have a passive internationalization (send more academics than receive) and this may be the case of most universities in these two countries.

Turkish state universities charge an annual enrollment fee of approximately $\$ 500$ to $\$ 2,000$, depending on the university or the course. In order for foreigners to be admitted, they must pass a test called "YOS" (Note 16) and present a high score in English proficiency tests like the TOEFL (Note 17) or IELTS (Note 18).

In order for applicants to be admitted in private universities, they need to show good grades $(80 \%)$ in high school and outstanding performance on the TOEFL or IELTS, but do not have to take the "YOS" test. The annual enrollment fee varies between $\$ 4,000$ and $\$ 8,000$, reaching $\$ 25,000$ for some courses like Dentistry and Medicine. In these private universities, many courses have programs in English and there is an increase of courses being offered in 
EMI.

\section{Results}

Out of 165 Turkish universities investigated, it is possible to observe that there is a higher number of state universities in the country, 62, that is,43\% (103) against 37,57\% (62) private institutions. There is one state university in each one of the 81 provinces, and 10 provinces have 2 or more state universities (Altinsoy, 2011). These results show an enormous contrast with Brazil with its 2.395 universities, of which only 4,68\% (103) are state (public) universities whereas 95,32\% (2.292) are private institutions. It is possible to say that both countries have the same number of state universities, though the proportion of state-versus-private universities is inverted. Though Brazil has a population 2,7 times bigger than Turkey, it is assumed that there is a market opportunity for private institutions in Brazil due to the lack of state universities for all the degree-seeker students. Indeed, this was one of the main conclusions in Finardi and Ortiz (2015) in terms of the motivation for internationalization in private and state universities in Brazil.

From the 103 Turkish state universities investigated, 84,47\% (87) have a website in Turkish and also in English while 15,53\% (16) do not have a website version in English. It is also possible to notice the number of Turkish university websites that have versions in other languages such as Russian (7 websites), Arabic (6 websites), German (1 website), Kurdish (1 website), French (1 website), and Persian (1 website).

In Brazil, out of the 103 websites of state universities analyzed, 35\% (36) have a website in Portuguese and English, while 65\% (67) do not have website in English. The analysis of Brazilian university websites also showed versions in other languages such as Spanish (14 websites), French ( 6 websites), Chinese ( 2 websites), Japanese ( 2 websites), Italian (1 website) and German (1 website). It is observed that out of 103 Turkish state universities, $80(77,67 \%)$ offer at least one program or course in English (EMI) while 23 (22,33\%) do not.

\section{Discussion}

The websites of the 103 Turkish universities investigated follow the same pattern in their electronic addresses "www.xxx.edu.tr". The websites offer links for social networks like Google+, Instagram, Tumblr, Facebook, and YouTube, suggesting an approximation to the public who use these social networks in their daily lives. Most websites also display information on Erasmus and Mevlana. To redirect the page to its version in English, one needs to click on the symbol "EN", English or on the United Kingdom flag at the superior bar of the website (Note 19). Upon clicking on the English version of the website, one notices an apparent offer to attract foreign students with tips about the country, admission, the city where the university is located, transportation, possibilities to learn Turkish, obtaining a visa, learning English, life style and cost of living in the country.

The analysis of the data indicates that there are more public universities in Turkey than private ones. Results of the contrastive analysis of Turkish and Brazilian state universities sites suggest that Turkish state universities are more oriented towards internationalization than Brazilian state universities. This suggestion can be confirmed by the number of Turkish and Brazilian state universities that have sites in English - almost 85\% in Turkey-against $35 \%$ in Brazil. This result seems to corroborate Finardi and Ortiz' (2015) suggestion that one 
of the reasons why Brazilian universities are not so eager to internationalize may be related to the size of the domestic market in Brazil. As we have shown in this paper, though the number of state universities in Turkey and Brazil is the same (103), the proportion between private versus state universities is inverted in these two countries with Turkey having more state (approximately 75\%) than private institutions (approximately 25\%), in Brazil the situation is the opposite with approximately the same proportion.

However, it is important to note the growth of private universities in Turkey and the offer of courses in English in these universities, which receive more international students and which are for financially privileged Turkish students, segregating those who do not have the same financial conditions or the language background.

Keeping in mind the number of Turkish academics that go abroad and the number of foreigners that come to Turkey to study, we can conclude that there is an unbalanced movement that favors unidirectional academic mobility type OUT in that country. However, taking into account the quality of the Turkish universities and the wish of the country to integrate the European Union, we can see efforts towards the internationalization type "IN" or "at home" with the offer of EMI courses in Turkish universities as well.

The European exchange program (Erasmus) and its Turkish (Mevlana) equivalent are the idealization of the Bologna Process since it is only through student scholarships that some of these students can pay academic tuitions and fees, as well as other costs related to their stay in another country.

The offer of English as medium of instruction courses certainly favors some but not all Turkish students. It is crucial that we analyze if the choice of English as medium of instruction in higher education stimulates or impedes multilingualism. Besides that, we must also reflect upon the possible consequences of offering EMI courses such as the poor performance of students in certain content areas due to their lack of proficiency in the language of instruction.

All in all we can say that Turkish EMI courses offer many prospects and challenges. We understand the limitations of this study as only quantitative data were analyzed, but we can infer from the data collected that the status of English in Turkey is at the center of discussions about globalization and the path that the country wants to trace towards the Western world and the model of development of the West.

\section{Conclusion}

The objective of this study was to analyze the number of state higher education institutions in Turkey that offer programs in EMI, totally or partially. In order to do that, 103 websites of Turkish universities were analyzed. From those, it was found that 23 universities offer EMI courses, reflecting the global demand and view that English is needed for a better allocation in the job market and the local demand to attract student-client's tuition payers.

State universities in Turkey outnumber the private ones. There are 103 state universities while there are only 62 private institutions in the country. From these 103 state universities, $77.6 \%$ (80 universities) of these institutions do not offer EMI courses in their programs, meaning that most of the EMI courses are offered in private institutions or in a limited number of public universities. This fact, in turn, deepens the social gap between those who can afford 
private education and, therefore, receive instruction in English and, most likely, increase their possibilities in the globalized world, and those who cannot.

It seems inevitable to learn English as an additional language in order to insert individuals in a global context, which is growing more Anglophone, but it is necessary to be critical of the use of English and remember that the propagation of this language is not apolitical. It is necessary to observe not only the consequences of studying a language that is not not a native language and, besides, the impact of EMI to the Turkish language and culture and to those who do not have access (both financial and linguistic) in a country surrounded by neighbors that have adopted EMI as a rule. Keeping in mind the necessity for internationalization both of the type (IN) and (OUT), we think that the motivation to learn Turkish is as important to the local demand as learning English is to the global demand. It is paramount to problematize these two demands in order to promote a more critical development and internationalization.

\section{References}

Akkari, Abdeljalil; GOHARD-RADENKOVIC, Aline. Coopération internationale: entre accommodements interculturels et utopies du changement. Paris: Harmattan, 2008.

Al-Bakri, S. (2015). Problematizing English medium instruction in Oman. International Journal of Bilingual \& Multilingual Teachers of English, 1(2), 55-69.

Alencar, J. (2016). Abordagem de Ensino de Língua Inglesa por Meio de Conteúdos e Formação de Professores: Apropriações, Possibilidades e Limitações. Master's Dissertation, Programa de Pós Graduação em Educação, Universidade Federal do Espírito Santo, Vitória.

Al-Faruqi, I. R. (1986). Toward Islamic English. USA: International Institute of Islamic Thought (IIIT), 64.

Altinsoy, S. (2011). A review of university facilities in Turkey. CELE Exchange, (No. 2011/06). OECD Publishing, Paris. https://doi.org/10.1787/5kg5c8cch88p-en

Ament, J. R., \& Pérez-Vidal, C. (2015). Linguistic outcomes of English medium instruction programmes in higher education: A study on economics undergraduates at a Catalan University. Higher Learning Research Communications, 57-68. https://doi.org/10.18870/hlrc.v5i1.239

Andreotti, V. de O., Stein, S., Ahenakew, C., \& Hunt, D. (2015) Mapping interpretations of decolonization in the context of higher education. Decolonization: Indigeneity, Education \& Society, 4(1), 21-40.

Arshad, N., \& Ahamad S. M. I. (2014). Lexical borrowing from the Arabic language in an Islamic course conducted in English. Middle-East Journal of Scientific Research, 20(14), $110-117$.

Castro-Goméz, S. (2007). Decolonizar la universidad. La hybris del punto cero y el diálogo de saberes. In: Castro-Goméz, Santiago; Grosfoguel, Ramón (Orgs.). El giro decolonial. Reflexiones para una diversidad epistémica más allá del capitalismo global. Bogotá: Siglo del Hombre Editores, pp. 79-91.

Crowther, P., Joris, M., Otten, M., Nilsson, B., Teekens, H., \& Wächter, B. (2000). Internationalisation at home: A position paper. P. Crowther (Ed.). Amsterdam: European Association for International Education. Retrieved from 
https://pdfs.semanticscholar.org/d52c/f2a5ec36d88c551b1155ccb60123650d8e5f.pdf, access Csillagh, V. (2015). Global trends and local realities: Lessons about economic benefits, selves and identity from a Swiss context. Studies in Second Language Learning and Teaching, 5(3), 431-453. https://doi.org/10.14746/ssllt.2015.5.3.5

Crystal, D. (2003). English as a global language. Ernst Klett Sprachen. https://doi.org/10.1017/cbo9780511486999

Dearden, J. (2014). English as a medium of instruction - a growing global phenomenon. British Council.

de Wit, H. (ed.) (2011). Internationalisation of Higher Education in Europe and its Assessment. In: Trends, Issues and Challenges in Internationalisation of Higher Education. Amsterdam: Hogeschool van Amsterdam, pp. 39-43.

Howard, D. (2001). The History of Turkey. London: Greenwood Press.

Ferguson, C. A. (1970). The role of Arabic in Ethiopia: a sociolinguistic perspective. Languages and Linguistics Monograph Series, 23, 355-368.

Finardi, K. R. (2017). What Brazil can learn from Multilingual Switzerland and its use of English as a Multilingua Franca. Acta Scientiarum (UEM), 39, 219-228. https://doi.org/10.4025/actascilangcult.v39i2.30529

Finardi, K. R.(2014). The Slaughter of Kachru's Five Sacred Cows in Brazil: Affordances of the Use of English as an International Language. Studies in English Language Teaching, 2(4), 401-411. https://doi.org/10.22158/selt.v2n4p401

Finardi, K.R., \& França, C. (2016). O inglês na internacionalização da produção científica brasileira: Evidências da subárea de linguagem e linguísitica. Intersecções (Jundiaí), 19, 234-250.

Finardi, K.R., Prebianca, G., \& Momm, F. (2013). Tecnologia na educação: o caso da internet e do inglês como linguagens de inclusão. Cadernos do IL, 46, 193-208.

Finardi, K. R., \& Ortiz, R. A. (2015). Globalization, Internationalization and Education: What is the Connection? IJAEDU-International E-Journal of Advances in Education, 1, 18-25.

Finardi, K. R., Santos, J., \& Guimarães, F. (2016). A Relação entre Línguas Estrangeiras e o Processo de Internacionalização: Evidências da Coordenação de Letramento Internacional de uma Universidade Federal. Interfaces Brasil/Canadá, 16, 233-255.

Finardi, K. R., \& Tyler, J. (2015). The role of English and technology in the internationalization of education: insights from the analysis of moocs. In 7th International Conference on Education and New Learning Technologies, 2015, Barcelona. Edulearn15 Proceedings. Barcelona: IATED, 1, 11-18.

Jenkins, J. (2013). English as a lingua franca in the international university: The politics of academic English language policy. New York, NY: Routledge.

Jenkins, J. (2015). Repositioning English and multilingualism in English as a Lingua Franca. Englishes in Practice, 2(3), 49-85. https://doi.org/10.1515/eip-2015-0003

Kirkpatrick, A. (2014). The language(s) of HE: EMI and/or ELF and/or multilingualism? The Asian Journal of Applied Linguistics, 1(1), 4-15.

Knight, J. (2003). Updated internationalization definition. International Higher Education, 33, 


\section{2-3.}

Liberali, F., \& Megale, A. (2016). Elite bilingual education in Brazil: an applied linguist's perspective. Colombian Applied Linguistics Journal, 18(2), 95-108. https://doi.org/10.14483/calj.v18n2.10022

Lima, M. C., \& Maranhão, C. M. S. A. (2009). O sistema de educação superior mundial: entre a internacionalização ativa e passiva. Avaliação. Campinas; Sorocaba, 14(4), 583-610. https://doi.org/10.1590/S1414-40772009000300004

Persson, L., \& Lundin, C. (2015). Advantages and Challenges with CLIL-a study examining teachers' thoughts on learner engagement and confidence within content and language integrated learning. Thesis. Malmö Högskola, Malmö.

Martinez, R. (2016). English as a Medium of Instruction (EMI) in Brazilian higher education. In Finardi, K. R.(Org.). English in Brazil: views, policies and programs. Eduel, 191-228.

Phillipson, R. (2009). Linguistic imperialism continued. New York, NY: Routledge.

Rocha, W. I., Correa, T. H., \& Salgado, A. (2010). Educação bilíngue e content based instruction: perspectivas para o ensino de línguas no Brasil. Eletras, 20(20).

Sylvén, L. (2015). CLIL and non-CLIL students' beliefs about language. Studies in Second Language Learning and Teaching, 2, 251-272. https://doi.org/10.14746/ssllt.2015.5.2.4

\section{Notes}

Note 1. EMI is understood here as the use of the English language to teach academic disciplines in countries whose first language (L1) is not English (DEARDEN, 2014).

Note 2. http://www.debatingeurope.eu

Note 3. www.profil.at

Note 4. www.ethnologue.com

Note 5.

http://www.esci-paris.eu/wp-content/uploads/2015/05/6-european-credit-transfer-accumulatio n-system.pdf

Note 6. www.esn.org

Note 7. www.erasmusprogramme.com

Note 8 .Available at www.geyc.ro, accessed on May 31st at 7:00 pm.

Note 9. Available at www.ec.europa.eu, accessed on May 31st at 7:00 pm.

Note 10. http://mevlana.en.ankara.edu.tr/?page_id=51

Note 11. Available at www.mevlana.en.ankara.edu.tr

Note 12. www.yok.gov.tr

Note 13. www.mevlana.istanbul.edu.tr

Note 14. www.studyinturkey.com

Note 15. www.edu.tr

Note 16. http://yos.istanbul.edu.tr/en/, accessed on May 31st at 6:50 pm.

Note 17. www.ets.org/toefl, accessed on May 31st at 6:45 pm. 
Note 18. www.ielts.org, accessed on May 31st at 6:45 pm

Note 19. It is interesting to note that though English is spoken in many countries, EMI is usually associated with British English

\section{Appendix}

List of Turkish Universities and their Respective Provinces

\begin{tabular}{|c|c|}
\hline Abant Izzet Baysal University & Bolu \\
\hline Abdullah Gul University & Kayseri \\
\hline Adana Science and Technology University & Adana \\
\hline Adiyaman University & Adiyaman \\
\hline Adnan Menderes University & Aydin \\
\hline Afyon Kocatepe University & Afyon \\
\hline Agri Ibrahim Cecen University & Agri \\
\hline Ahi Evran University & Kirsehir \\
\hline Akdeniz University & Antalya \\
\hline Aksaray University & Aksaray \\
\hline Amasya University & Amasya \\
\hline Anadolu University & Eskisehir \\
\hline Ankara University & Ankara \\
\hline Artvin Coruh University & Artvin \\
\hline Ardahan University & Ardahan \\
\hline Ataturk University & Erzurum \\
\hline Balikesir University & Balikesir \\
\hline Bartin University & Bartin \\
\hline Batman University & Batman \\
\hline Bayburt University & Bayburt \\
\hline Bilecik Seyh Edebali University & Bilecik \\
\hline Bingol University & Bingol \\
\hline Bitlis Eren University & Bitlis \\
\hline Bogazici University & Istanbul \\
\hline Bozok University & Yozgat \\
\hline Bursa Technical University & Bursa \\
\hline
\end{tabular}




\begin{tabular}{|c|c|}
\hline Bulent Ecevit University & Zonguldak \\
\hline Celal Bayar University & Manisa \\
\hline Cumhuriyet University & Sivas \\
\hline Canakkale Onsekiz Mart University & Canakkale \\
\hline Cankiri Karatekin University & Cankiri \\
\hline Cukurova University & Adana \\
\hline Dicle University & Diyarbakir \\
\hline Dokuz Eylul University & Izmir \\
\hline Dumlupinar University & Kutahya \\
\hline Duzce University & Duzce \\
\hline Ege University & Izmir \\
\hline Erciyes University & Kayseri \\
\hline Erzincan University & Erzincan \\
\hline Erzurum Technical University & Erzurum \\
\hline Eskisehir Osmangazi University & Eskisehir \\
\hline Firat University & Elazig \\
\hline Galatasaray University & Istanbul \\
\hline Gazi University & Ankara \\
\hline Gaziantep University & Gaziantep \\
\hline Gaziosmanpasa University & Tokat \\
\hline Gebze High Technology Institute & Kocaeli \\
\hline Giresun University & Giresun \\
\hline Gumushane University & Gumushane \\
\hline Hacettepe University & Ankara \\
\hline Hakkari University & Hakkari \\
\hline Harran University & Sanliurfa \\
\hline Hitit University & Corum \\
\hline Igdir University & Igdir \\
\hline Istanbul Medeniyet University & Istanbul \\
\hline Inonu University & Malatya \\
\hline Istanbul University & Istanbul \\
\hline Istanbul Technical University & Istanbul \\
\hline
\end{tabular}




\begin{tabular}{|c|c|}
\hline Izmir Katip Celebi University & Izmir \\
\hline Izmir High Technology Institute & Izmir \\
\hline Kafkas University & Kars \\
\hline Kahramanmaras Sutcu Imam University & Kahramanmaras \\
\hline Karabuk University & Karabuk \\
\hline Karamanoglu Mehmetbey University & Karaman \\
\hline Karadeniz Technical University & Trabzon \\
\hline Kastamonu University & Kastamonu \\
\hline Kirikkale University & Kirikkale \\
\hline Kirklareli University & Kirklareli \\
\hline Kilis 7 Aralik University & Kilis \\
\hline Kocaeli University & Kocaeli \\
\hline Mardin Artuklu University & Mardin \\
\hline Marmara University & Istanbul \\
\hline Mehmet Akif Ersoy University & Burdur \\
\hline Mersin University & Mersin \\
\hline Mimar Sinan University & Istanbul \\
\hline Mugla Sitki Kocman University & Mugla \\
\hline Mustafa Kemal University & Antakya \\
\hline Mus Alparslan University & Mus \\
\hline Namik Kemal University & Tekirdag \\
\hline Necmettin Erbakan University & Konya \\
\hline Nevsehir University & Nevsehir \\
\hline Nigde Omer Halisdemir University & Nigde \\
\hline Ondokuz Mayis University & Samsun \\
\hline Ordu University & Ordu \\
\hline Orta Dogu Technical University & Ankara \\
\hline Osmaniye Korkut Ata University & Osmaniye \\
\hline Pamukkale University & Denizli \\
\hline Recep Tayyip Erdogan University & Rize \\
\hline Sakarya University & Sakarya \\
\hline Selcuk University & Konya \\
\hline
\end{tabular}




\begin{tabular}{|l|l|}
\hline Siirt University & Siirt \\
\hline Sinop University & Sinop \\
\hline Suleyman Demirel University & Isparta \\
\hline Sirnak University & Sirnak \\
\hline Trakya University & Edirne \\
\hline Tunceli Munzur University & Tunceli \\
\hline Turk-Alman University & Istanbul \\
\hline Uludag University & Bursa \\
\hline Usak University & Usak \\
\hline Yalova University & Yalova \\
\hline Yildirim Beyazit University & Ankara \\
\hline Yildiz Technical University & Istanbul \\
\hline Yuzuncu Yil University & Van \\
\hline
\end{tabular}

\section{Copyright Disclaimer}

Copyright reserved by the author(s).

This article is an open-access article distributed under the terms and conditions of the Creative Commons Attribution license (http://creativecommons.org/licenses/by/3.0/). 